\title{
SENTINEL 2 IMAGERY AND BURN RATIOS FOR ASSESSING THE JULY 5, 2021 WILDFIRES SEVERITY IN THE REGION OF KHENCHELA (NORTHEAST ALGERIA)
}

\begin{abstract}
Nouar BOULGHOBRA ${ }^{1}$ (i)
DOI : 10.21163/GT_2021.162.08

ABSTRACT:

Wildfire events are majeure natural risks occurring in multiple ecosystems worldwide, and lead to significant damages on their human, ecological and socioeconomic components. This research interested on evaluating and mapping the recent and exceptional wildfires occurred in the Aures Mounts System near Ain Mimoun in July 5, 2021. Multidates Sentinel 2 images, the differenced Normalized Burn Ratio dNBR and its Relativized dNBR (RdNBR) have been used for extract and evaluate the recently burned areas. Results reveal that he July 5 wildfires lead to the loss of 6,607 ha (9\%) of Aleppo pine forest cover and municipalities of Tamza and Chelia were more damaged, with respectively 4,143 and 2,166 ha of burned superficies. In addition to the high-vulnerability to fire risk occurrence, essentially due to topographic and morphological features, the study area exhibited also favoring climatic features before and during the fire event occurrence, high daily temperatures and high variable wind directions were prominent factors in accelerating the fire spreading and increasing the fire extent. This study concludes that Sentinel 2, dNBR and especially RdNBR are effective geoinformatic data and indices for assessing, classifying and mapping burn severity extent due to wildfire events. To attenuate damages, it is necessary to adopt risk mitigation plans based on efficient measures to be applied before, during and after the fire events occurrence.
\end{abstract}

Key-words: Wildfire, July 5, Khenchela, Sentinel 2, Relativized Burn Ratio

\section{INTRODUCTION}

Forest fires occur in multiple regions worldwide and have been subject of many researches, interested essentially on assessment, mapping, and risk evaluation using often geomatic-based approaches (Rogan \& Franklin, 2001; Roy et al., 2006; Furtună \& Holobâcă, 2013; Parks et al., 2014; Arellano et al., 2017; Parajuli et al., 2020), and often by adopting field measurement-based methodologies (Cocke et al., 2005; Cai \& Wang, 2020).

In addition to the man-made activities, northern Mediterranean ecosystems are characterized by highly favoring climatic and physical circumstances for the forest fire occurrence, leading to multiple and repetitive wildfires events in France, Italy, Spain and Greece, especially during the last two decades, leading to significant damages (San-Miguel-Ayanz et al., 2017). In the southern Mediterranean, Algeria is facing important and recurrent forest fire risk events. According to Madoui (2002), 118,624 ha of forest areas were loosed due to fires from 1979 to 1995 . Causes of forest fires in Algeria are multiples; according to Benkheira (2018), $75 \%$ are of unknown causes, $23 \%$ are due to premeditated human activity and $2 \%$ are related to agricultural activities.

Northeast Algeria, the Aures Mountains belong to the Saharan Atlas System; this region is characterized by high altitudes (up to $2,328 \mathrm{~m}$ ), that this is the main reason for receiving more than $1,000 \mathrm{~m}$ of annual precipitation (Meharzi, 1994), leading to the growth of important forest cover. The Aures region is suffering a critical occurrence of forest fires events; according to the forest conservatory of Khenchela, more than 40 wildfires took place in the Aures from 2016 to 2018. Nevertheless, few researches interested in studying, assessing and mapping this major hazard: Rahmani and Benmassoud (2019) used remotely sensed data and GIS for modeling and mapping the

\footnotetext{
${ }^{1}$ Scientific and Technical Research Centre on the Arid Regions CRSTRA, University campus Mohamed Keider, BP 1682 RP, Biskra07000, Algeria, boulghobra.n@gmail.com
} 
Forest fire hazard in the region of Khenchela, by applying the Analytical Hierarchy Process AHP method considering related factors, namely vegetation types, topography and the anthropogenic activities. They reported that the Aures Mountain forests are considered as highly vulnerable to the wildfire hazard. The United Nations Satellite Centre and United Nations Institute for Training and Research (UNOSAT/UNITAR, 2012) used fine resolution RapidEye satellite imagery satellite for assessing and mapping the August 18, 2012 wildfires in the Aures Mountains (Regions of Biskra, Batna and Khenchela), they reported that wildfire damaged about $295 \mathrm{Km} 2$ (29,500 ha) of pine and oak forests. The year 2021 presented extreme meteorological conditions across entire Algeria, exceptional temperatures and heat waves exceeding $45^{\circ} \mathrm{C}\left(113{ }^{\circ} \mathrm{F}\right)$ during late June, led to a multiplicity of wildfires in multiples regions such as Tebessa (Mountains of El-Atef) and Tikjda (Tell Atlas in Bouira governorate). In the region of Aures System west of the city of Khenchela, a wide wildfire took place in July 5 near the Ain Mimoun. During 5 days (July 5 to 10), the fires spreads in different directions and damaged significant forest superficies through Tamza, Chelia, Bouhmama and Ain Ouanjal municipalities, official preliminary reports declare the wildfires as man-made caused and estimate the forest loss to be 8,245 ha.

This research aims to assess and mapping the July 5, 2021 wildfires extents in the region of Khenchela, using time-series of Sentinel 2 images, and the relativized burn radio index RdNBR for extracting burnt superficies through the damaged municipalities. The study also interested on analyzing and understanding the climatic and topo-morphological circumstances of this wildfire genesis and propagation.

\section{STUDY AREA}

The study area is located west of the city of Khenchela (400,000 habitants), it extends over a superficies of $921 \mathrm{Km} 2$ (921,000 ha) and encloses 10 municipalities. Topographic pattern highlights the predominance of highly elevated landscape (Fig. 1) composed of prominent mountains (Djebel in Ar.) and hells (Kef, Rass in Ar.): Dj. Djahfa in the south $(1,571 \mathrm{~m})$, the west-east chain alignment of Dj. Chelia (2,328m), Dj. Faraoun (2,071m), Kef Tifekrissa (1,900m) and Rass Serdoune $(1,671 \mathrm{~m})$, in addition to the northern parallel chain mainly composed of Dj. Aures $(1,571 \mathrm{~m})$, Dj. Tizi Ala $(1,271 \mathrm{~m})$.

(C)

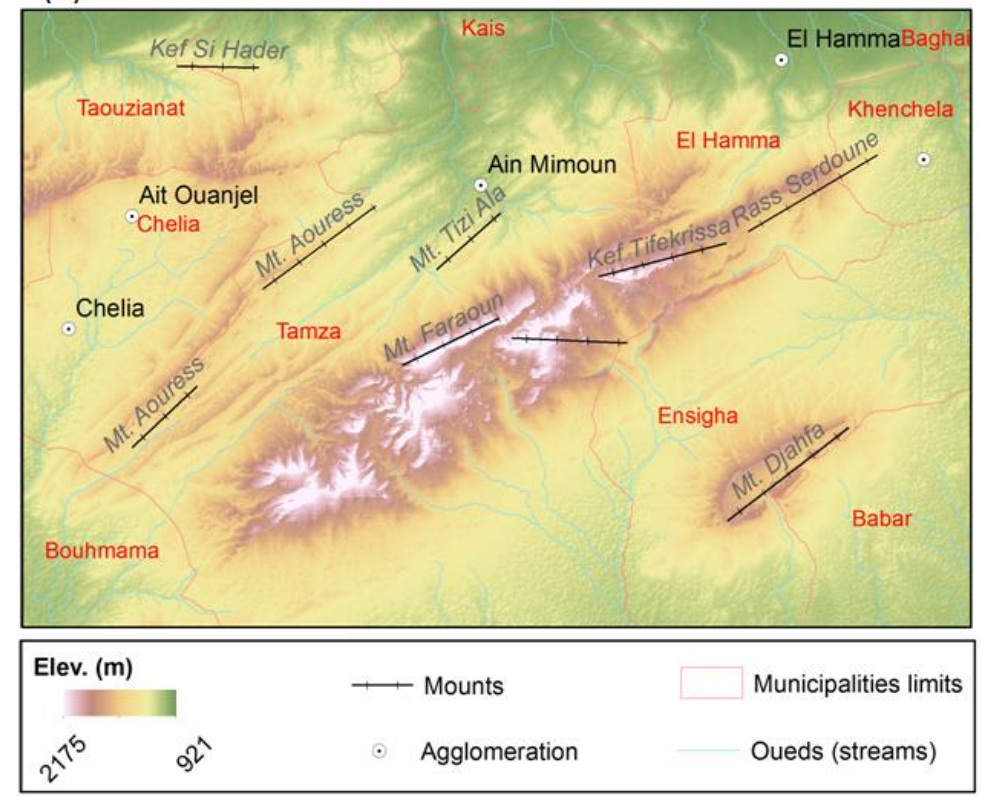

(A)

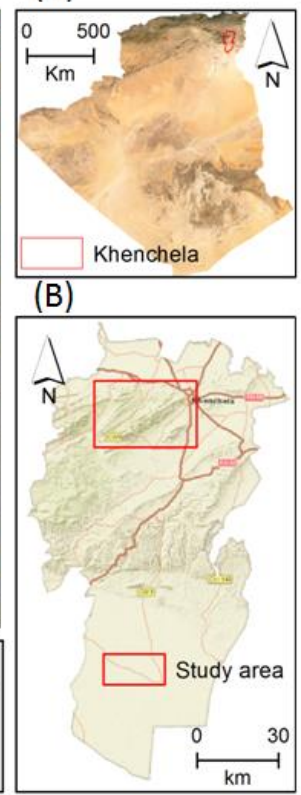

Fig. 1. (A) Localization of Khenchela governorate in northeast Algeria. (B) Localization of the study area in north of Khenchela. (C) Digital Elevation Model DEM by the Shuttle Radar Topography Mission SRTM of 40X40m resolution (www.usgs.gov), showing the major hypsometric patterns of the study area 
Regarding the geological map by Kazi Tani and Oussedik (1977), the high-lands lithology is mainly composed of lower cretaceous (Aptian limestone), Albian marls, sandstones and dolomite in the middle areas; northern parts are composed of Tortonian Miocene sandstones, whereas low-lands parts correspond to quaternary plains. The region of Khenchela is characterized by Mediterranean climate, mean temperatures range from $1.8^{\circ} \mathrm{C}$ in January to $27{ }^{\circ} \mathrm{C}$ in July; maximum temperatures could reach $40{ }^{\circ} \mathrm{C}$. Mean annual precipitation is about $400 \mathrm{~mm}$ in the meteorological station of El Hamma (987m ASL). However, rainfalls can reach 1,200mm depending on altitudes and exposure (Meharzi, 1994); these conditions contrast leads to the growth of important forest cover essentially composed of Aleppo pine (Pinus halepensi), Altas cedar (Cedrus atlantica), Holm oak (Quercus ilex) and Juniper (Juniperus), often protected as biosphere reserves and national parks.

\section{DATA AND METHODS}

\subsection{Satellite imagery}

For geospatially assessing and mapping of the July 5, 2021 wildfires extent in the region of Khenchela, it had been necessary to use multi dates satellite images corresponding to the pre, during and post fire phases. In addition to the required analysis scale and the study purpose, availability was a determinant criterion for choosing the data type. Time-series of high-resolution optical imagery were used, namely the Sentinel 2 (Copernicus Program) images dated May 21, July 5 and July 10, corresponding respectively to the pre, during and post fires phases. In total, 6 images were used since it was necessary to constitute image mosaic for each date, by assembling tiles couple having the scene centers (path/row) 193/035 and 193/036. Images are open source available, they present minimum cloud cover (less than $1 \%$ ); they are of Level-2A quality, i.e. are atmospherically corrected and are orthorectified and projected according to the Universal Transverse Mercator system zone 32.

Each satellite image provides multi spectral bands in both visible and infrared domains, wavelengths are ranging from the blue $(0.458-0.522 \mu \mathrm{m})$ to the short wave infra red SWIR $2(2.100-$ $2.280 \mu \mathrm{m})$. After converting the bands on Geotiff format, and being of $20 \mathrm{~m}$ of spatial resolution, the Short Wave Infra-Red 1 (SWIR 1) and Short Wave Infra-Red 2 (SWIR 2) bands were resampled to $10 \mathrm{~m}$ to be spatially homogenized with the visible domain bands resolution. Besides, images were calibrated from radiance to surface reflectance to allow calculating the required spectral indices.

\subsection{Differenced Normalized and Relativized Burn Ratios for extracting burned areas}

Extraction of the damaged superficies due to wildfires in the study area was performed using the Normalized Burn Ratio NBR (ranging from -1 to 1); this derived index is based on the Near Infrared (NIR) and the Shortwave Infrared 2 (SWIR2) bands of the Sentinel 2 images, it is based on peak reflectance of both vegetation and mineral soil to provide an index of the amount of vegetation present on the landscape before and after the fire event, and this according to the formulae:

where:

$$
N B R=\frac{N I R-S W I R 2}{N I R+S W I R 2}
$$

NBR - Normalized Burn Ratio

NIR - Near Infrared

SWIR2 - Shortwave Infrared 2

Spectrally, the NBR is the opposite of the Normalized Difference Vegetation Index NDVI developed by Rouse et al. (1974), which refers to the NIR and Red spectral bands, and often used to discriminate vegetative cover abundance. Burned areas correspond to low reflectance pixels in the Near Infrared and high reflectance in the Short Wave Infra-Red 2 band; consequently, high NBR values indicate abundant vegetation, whereas very low values (close to -1) indicate recently burnt areas. For both pre fire (May 21) and post fire (July 10) images, NBR was calculated under Geographic Information System software; thereafter, recently burned areas due to the July 5 wildfire could be than calculated using the bi-dates difference according to the formulae: 
where:

$$
d N B R=N B R_{\text {pre-fire }}-N B R_{\text {post }- \text { fire }}
$$

dNBR - bi-dates difference

$N B R$ pre-fire $-N B R$ of pre fire images

$N B R$ post-fire - NBR of post fire images

However, dNBR values could be influenced by the atmospheric conditions during image acquisition, this contributes on confusing recently burned areas and originally unvegetated superficies during the pre fire phase (Roy et al., 2006; Rose et al., 2016). Parks et al. (2014) suggest using the Relativized Burn Ratio RdNBR for being more accurate and reliable in measuring and classifying burn severity. RdNBR severity maps could provide an adequate assessment of the degree of damages (Mallinis et al., 2018; Konkathi \& Shetty, 2021); it can be calculated according to the following equation:

where:

$$
R d N B R=\frac{d N B R}{N B R_{\text {pre-fire }}+1.001}
$$

\section{RdNBR - Relativized Burn Ratio}

Both dNBR and RdNBR produced maps were classified into different fire severity levels, based on the scale developed by the U.S. Geological Survey Earth Resources Observation and Science Center (Table 1). Spatial distribution of different burn severity percentages was carried out, mapped and discussed.

Table 1.

Fire severity levels assigned to dNBR classes.

\begin{tabular}{lll}
\hline Severity No. & Severity Level & dNBR range \\
\hline 1 & Enhanced Regrowth, High & $\leq-0.251$ \\
2 & Enhanced Regrowth, Low & -0.250 to -0.101 \\
3 & Unburnt & -0.100 to 0.099 \\
4 & Low Severity & 0.100 to 0.269 \\
5 & Moderate-Low Severity & 0.270 to 0.439 \\
6 & Moderate-High Severity & 0.440 to 0.659 \\
7 & High Severity & $\geq 0.660$ \\
\hline
\end{tabular}

\section{RESULTS AND DISCUSSION}

\subsection{Wildfire vulnerability and pre fire circumstances}

The ignition and combustion initiation require the presence of external heat source, combustible materials (as vegetation) and oxygen; afterward, the wildfire intensity and propagation depend on multiple factors such as climatic conditions (wind velocity/direction, temperature, humidity...), physical context of the ecosystem (slopes, aspect, morphology ...) and the vegetation types and composition (Merdas, 2007). The combination of these factors increases forest ecosystem vulnerability to fire occurrence. According to Rahmani and Benmassoud (2019), the Aures Mounts forests are high-risk regions, presenting highly favorable conditions to fire propagation, and this is due to multiple factors: 1) Predominance of high relief associated with steep slopes exceeding $45 \%$; 2) Predominance of medium to high piedmonts and mountains landscapes and; 3 ) the land cover is mainly constituted of high-combustibility species as Holm oak and Aleppo pine. Besides, the year 2021 is characterized with exceptional heat waves occurrences through entire Algeria reaching $49^{\circ} \mathrm{C}$ in Saharan regions; the region of Khenchela as well was marked by extremes daily records, the July 5 wildfire was preceded by long period of ascending temperatures. From June 24 to July 5, daily maximum temperatures exhibit a continuous increasing from 39 to $44{ }^{\circ} \mathrm{C}$; in associated with high 
evapotranspiration and pluviometric drought, this could contribute on considerably favoring the fire occurrence aptitude, which was initiated July 5 near Ain Mimoun agglomeration.

\subsection{Wildfire initiation and propagation}

First fire events initiated July 5, 2021 near the village of Ain Mimoun. Investigation of the duringfire Sentinel 2 image which was taken at 10:21 AM , allows to visualize a series of $20 \mathrm{~km}$ length and oriented southwest-northeast, composed of multiples and scattered ongoing fires exceeding 20 sites (Fig. 2B), signifying that fires were simultaneously initiated (at least timely close), and that they rapidly spread during short time.

Regarding the elevation map, it can be noticed that all of the fires occurred in the Mounts: Dj. Aouress (northwest), Dj. Tizi Ala (north) and Dj. Faraoun (south) on high altitudes, and along steep slopes, this can a favoring factor in fires spreading. Besides, wind direction was also a determinant agent since it was highly variable. In July 5 , wind direction was $125^{\circ}$ azimuth and oriented south east (Fig. 2A); July 6, air temperature increased to be $45^{\circ}$, daily-wind as well changed direction to be $70^{\circ}$ and oriented north-east east, July 7 it changed to $258^{\circ}$ according to the west-south west trend, this could be recognized and confirmed by visualizing the wildfire smoke trend (Fig. 2C). Later, wind directions were as well changed to $200^{\circ}$ and $245^{\circ}$ during July 8 and July 9 respectively (Fig. 2D). Therefore, highly-changing wind directional variability could be a major factor in rapid propagation of the fires, especially in presence of highly-combustible forest specie as Aleppo pine (Mitsopoulos \& Dimitrakopoulos, 2007).

(A)

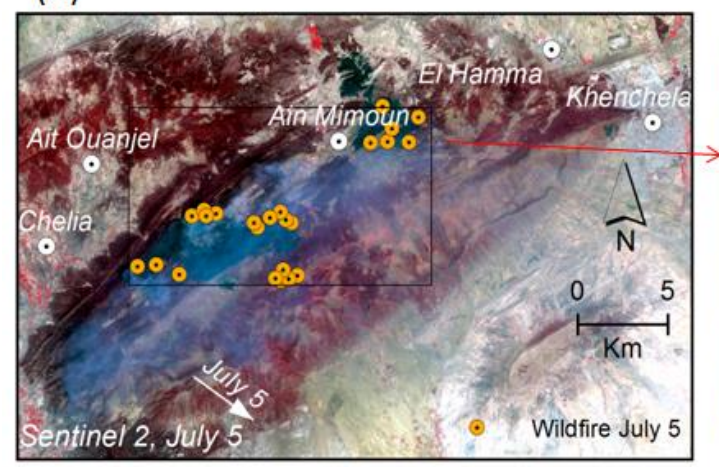

(C)

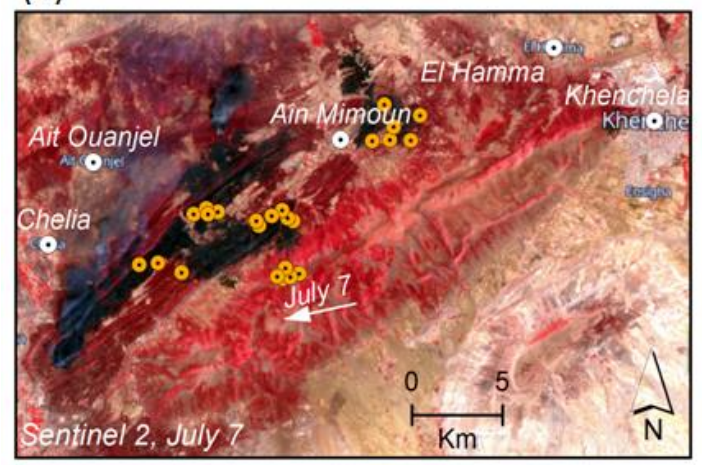

(B)

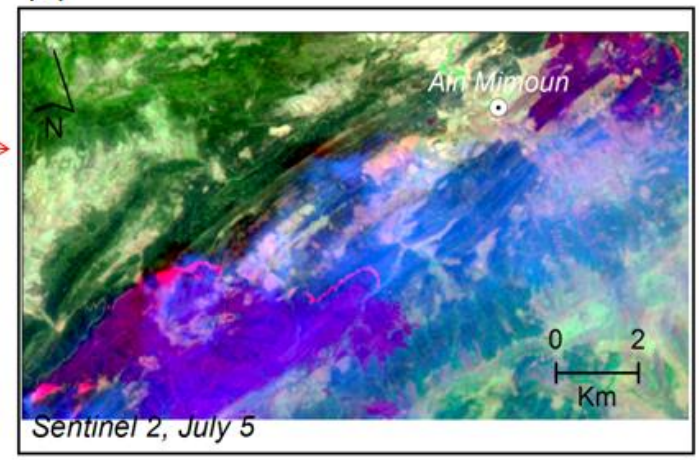

(D)

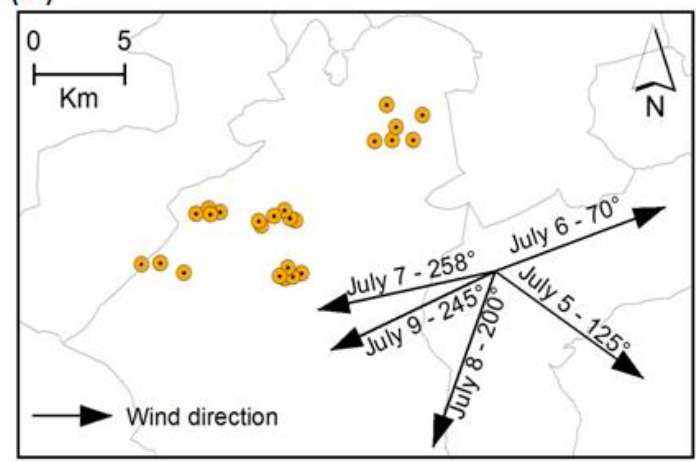

Fig. 2. (A) False color composite B8-B4-B3 of the Sentinel 2 image dated July 5 (during fire), with superimposed ongoing wildfire sites, note that the smoke direction is corresponding to the wind direction. (B) Excerpt of the July 5 image showing ongoing-fires in orange color. (C) False color composite B8-B4-B3 of the Sentinel 2 image dated July 7 (during fire); note that the smoke direction changed trending as response to the daily-wind direction. (D) Wind-rose showing directional variability from July 5 (fire starting) to July 9; note that the fire spreading was accelerated due to the high wind variability 


\subsection{Post fires and burned areas distribution}

After 5 days of activity, the fire events were completely ended July 10; consequently, daily temperatures decrease gradually from $43^{\circ} \mathrm{C}$ in July 10 to $33^{\circ} \mathrm{C}$ in July 17 .

The pre fire NBR map was ranged from -0.88 (no vegetation/bare soil) to 0.93 corresponding to healthy vegetation cover (variable-density Aleppo pine), the post fire NBR map presents a significant changing in pixel values that ranged from -0.97 to 0.98 , where very low values correspond spatially to moderate and dense forest during the pre fire period.

Table 2 and table 3 summarize rates and distribution of burn severity levels, respectively based on the reclassification of dNBR (Fig. 3A) and RdNBR maps (Fig. 3B); burnt areas are also evaluated and delimitated (Fig. 3C, Fig. 3D).

Table 2.

Distribution of burnt areas based on differenced normalized burn ratio dNBR.

\begin{tabular}{lllllll}
\hline \multirow{2}{*}{ Fire Severity classes } & \multicolumn{2}{l}{ Municipalities } & & & \multirow{2}{*}{ Total (ha) } & \multirow{2}{*}{ Total (\%) } \\
\cline { 2 - 5 } & Bouhmama & Tamza & Chelia & Kais & & \\
\hline Enhanced Regrowth, High & 0 & 0 & 2 & 0 & 3 & 0 \\
Enhanced Regrowth, Low & 0 & 44 & 9 & 0 & 53 & 0 \\
Unburnt & 2,971 & 31,454 & 19,219 & 1,731 & 55,375 & 73 \\
Low Severity & 348 & 5,078 & 3,038 & 464 & 8,929 & 12 \\
Moderate-Low Severity & 88 & 2,099 & 1,206 & 14 & 3,407 & 4 \\
Moderate-High Severity & 185 & 1,653 & 861 & 16 & 2,715 & 4 \\
High Severity & 150 & 3,461 & 1,838 & 11 & 5,459 & 7 \\
\hline Total & 3,742 & 43,789 & 26,173 & 2,237 & 75,941 & 100 \\
\hline Subtotal High Severity (burnt) & 335 & 5,114 & 2,698 & 27 & 8,175 & 11 \\
\hline
\end{tabular}

Table 3.

Distribution of burnt areas based on relativized burn ratio RdNBR.

\begin{tabular}{lllllll}
\hline \multirow{2}{*}{ Fire Severity classes } & \multicolumn{3}{l}{ Municipalities } & \multicolumn{2}{c}{ Total (ha) } & \multirow{2}{*}{ Total (\%) } \\
\cline { 2 - 6 } & Bouhmama & Tamza & Chelia & Kais & & \\
\hline Enhanced Regrowth, High & 0 & 1 & 4 & 0 & 5 & 0 \\
Enhanced Regrowth, Low & 0 & 14 & 7 & 0 & 21 & 0 \\
Unburnt & 3,061 & 32,341 & 19,617 & 1,770 & 56,789 & 75 \\
Low Severity & 267 & 5,365 & 3,377 & 433 & 9,442 & 12 \\
Moderate-Low Severity & 135 & 1,925 & 1,002 & 15 & 3,077 & 4 \\
Moderate-High Severity & 224 & 2,343 & 1,367 & 19 & 3,953 & 5 \\
High Severity & 55 & 1,800 & 799 & 1 & 2,654 & 3 \\
\hline Total & 3,742 & 43,789 & 26,173 & 2,237 & 75,941 & 100 \\
\hline Subtotal High Severity (burnt) & 279 & 4,143 & 2,166 & 19 & 6,607 & 9 \\
\hline
\end{tabular}

Based on both dNBR and RdNBR maps, no significant high and low enhanced regrowth occurs, unburnt area classes predominates with respectively 73 and $75 \%$, only $12 \%$ of the forest cover is of low severity and $4 \%$ is of moderate-low severity. In addition to the localization of ongoing fire sites on the during-fire image dated July 5 (Fig. 2A), the visualization and interpretation of the post fire image confirm that these classes correspond to unburnt areas. In the opposite, high and moderate-high severity classes (dNBR or RdNBR $\geq 0.440$ ) correspond to the effective total of burnt areas. By considering dNBR, total burnt area is about 8,175 ha $(11 \%)$ with more damages in Tamza $(5,114$ ha) and Chelia (2,698 ha). Differently, the total of effective burnt areas based on RdNBR is about 6,607 ha (9\%), distributed on 4 main municipalities: Tamza (4,143 ha), Chelia (2,166 ha), Bouhmama (279 ha) and kais (19 ha).

The accuracy of both dNBR and RdNBR in assessing burn severity is carried out; dNBR index is often overestimating damaged areas by presenting bias due to considering unburnt areas (Fig. 3E), RdNBR is more accurate since it delimitates high severity class in well accordance with effective burnt areas (Fig. 3F), this conclusion is in coherence with many similar studies (Arellano et al., 2017; 
Quintano et al., 2018; Konkathi \& Shetty, 2021) confirming that relativized dNBR is more appropriate and accurate in assessing high severity due to wildfires using Sentinel 2 and Landsat images.

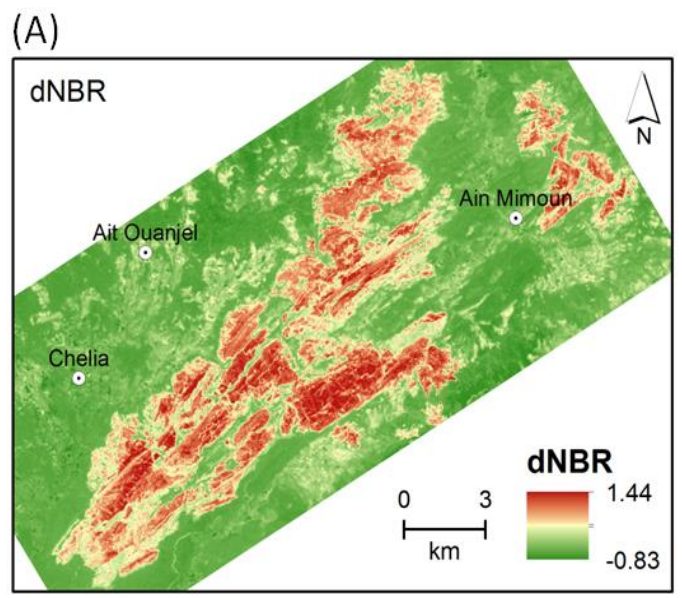

(B)
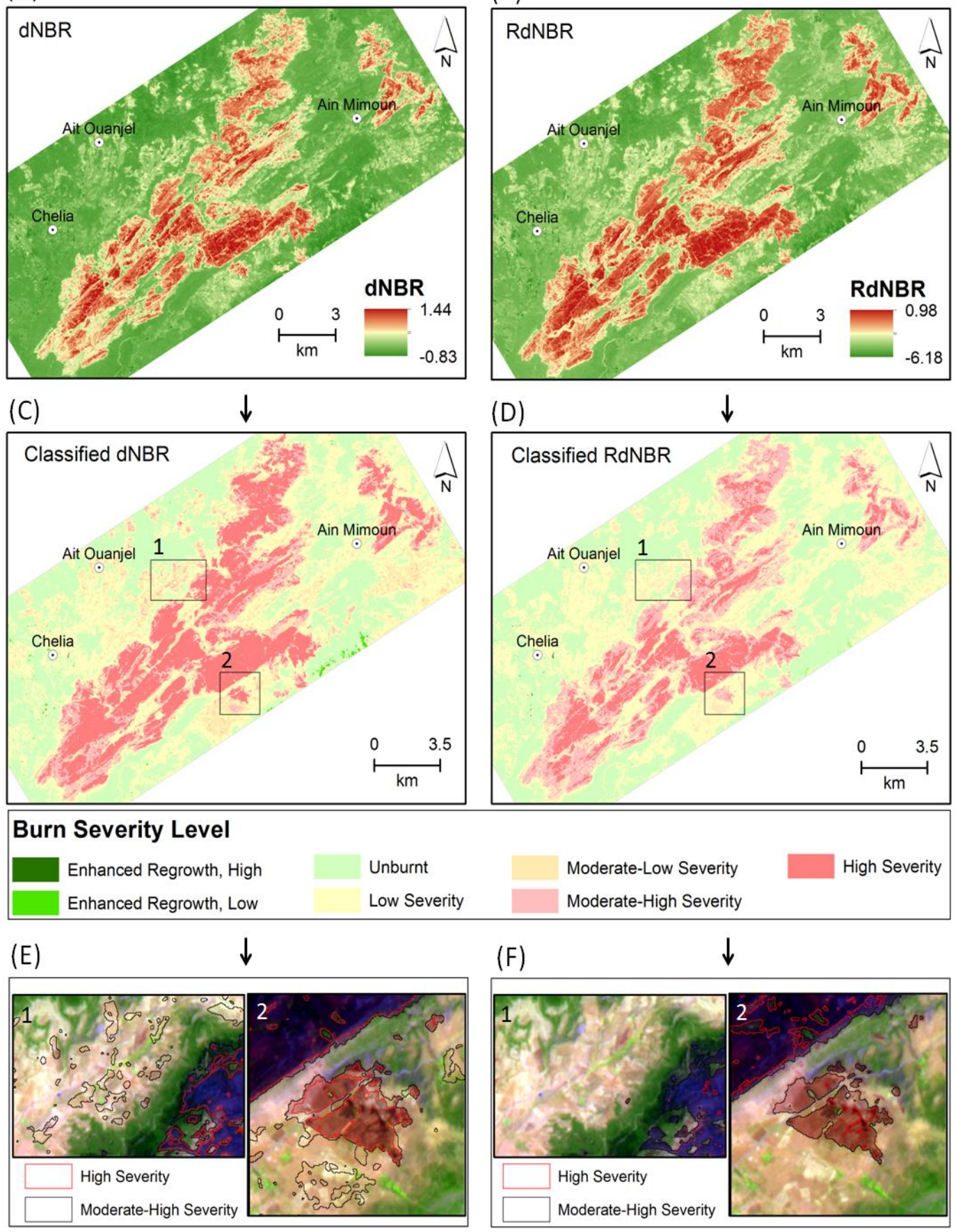

Fig. 3. (A) dNBR map showing delta NBR of pre and post fire. (B) RdNBR map. (C) Classified dNBR map showing severity level classes. (D) Classified RdNBR map showing severity level classes. (E) Zoom-in excerpts showing high fire severity precision based on dNBR classification. (F) Zoom-in excerpts showing high fire severity precision based on RdNBR classification 
Most of the fires occurred in the northern mounts series, Tamza situated in the south-facing versant and Chelia located in the north-facing versant, they were the most damaged municipalities with $100 \%$ of the total burned superficies. South, the higher mounts of $\mathrm{Dj}$. Faraoun is separated from the northern mounts series by a relatively flat piedmont of low slopes (less than $15 \%$ ); this natural character could be the limiting factor of fires spreading toward more southern areas. In addition to the topo-morphological consideration, the $0.5 \mathrm{~mm}$ precipitation occurred in July 7 could be a contributing factor in decreasing the combustibity aptitudes, and consequently limiting fire-propagation speed. 6,607 ha as total burned areas represent about $0.9 \%$ from the east-Algerian forest superficies $(800,239$ ha), and $5 \%$ from the total forest cover of Khenchela governorate estimated at 131,069 ha; the July 5, 2021 fire event is the second most degrading wildfires occurring in Khenchela after the August 18, 2012 which leaded to the loss of 15,000 ha and the emission of $1,000 \mathrm{Gg}$ of $\mathrm{CO} 2$ equivalent (Benkheira, 2018).

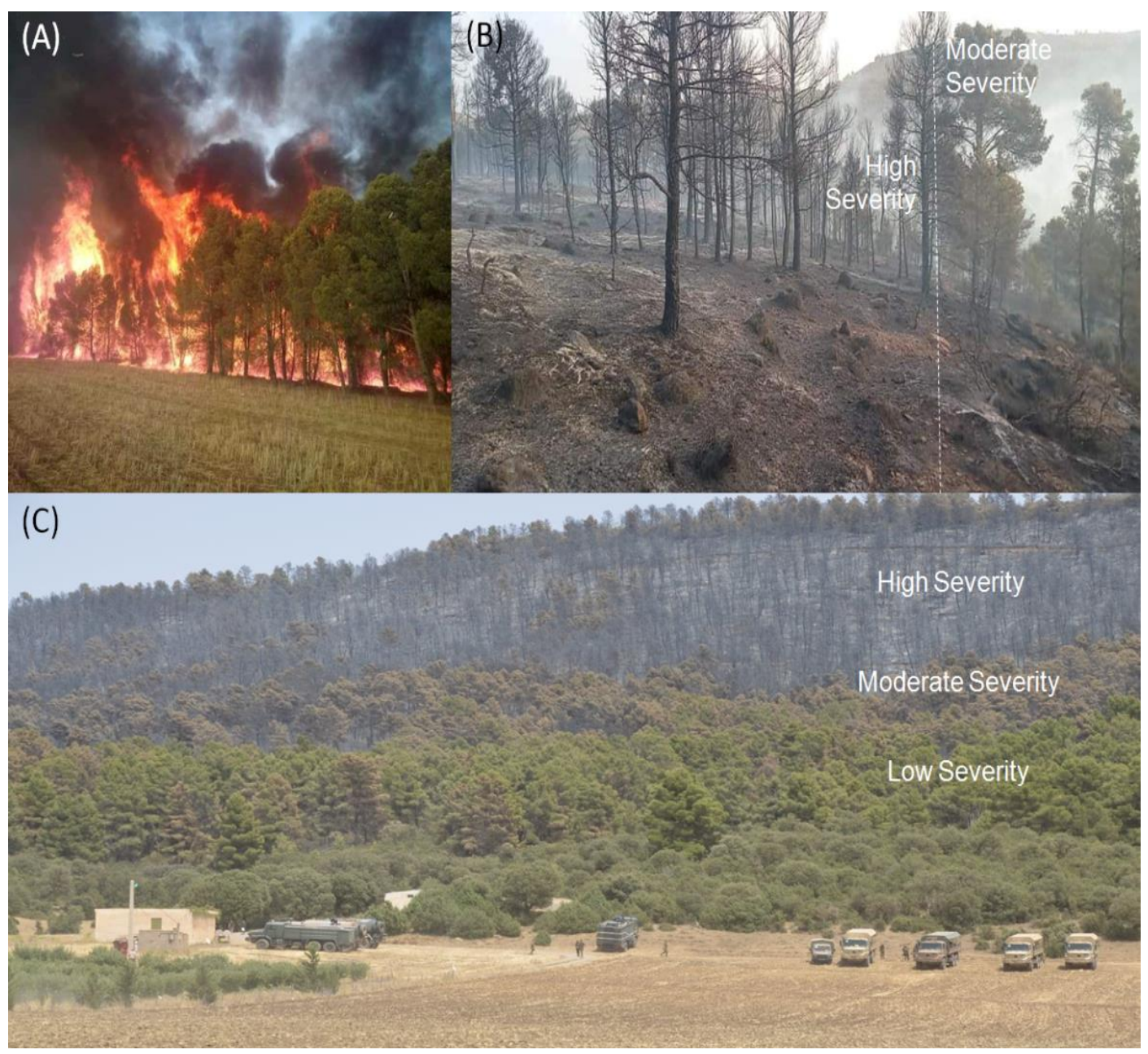

Fig. 4. (A) Ongoing wildfire dated July 5, 2021. (B) Juxtaposed moderate and high burn severity areas, note that high severity areas manifest damages in all stratums, whereas moderate severity areas is marked by unburnt tree stratum. (C) Juxtaposed low, moderate and high burn severity areas, note that highly burnt areas correspond to the cliff steep slopes that is a favoring factor is fire propagation. Photos courtesy by the forest directorate of Khenchela, cell of communication (2021) 


\section{CONCLUSION}

This research is a case study conducted in the Aures Mounts System east of Khenchela, Algeria. It was interested on assessing the fire severity levels, and delimitating recent burnt areas due to the wildfires occurred near Ain Mimoun in July 5, 2021, using multidates Sentinel 2 satellite imagery and burn ratios.

Results revealed that the July 5 fire event was due to favoring climatic, natural and topomorphological factors to the forest fire initiation and propagation, and this during pre and post fire phases. The domination of highly-elevated landscape characterized by steep slopes piedmonts, the dominance of highly-combustible trees species as Aleppo pine, are main factors in classifying the entire Aures Mounts among the high fire risk regions. The wildfire day was preceded by a long period of high and continuous daily temperature, this was a prominent factor on increasing the fire occurrence, the post fire period also was marked by highly-variable wind direction and, this pattern may be a determinant factor in the wildfire propagation during 5 days.

Based on differenced normalized burn ratio dNBR, highly-burnt area was assessed to be 8,175 ha. Differently, relativized dNBR allowed to accurately evaluating highly-damaged areas to be 6,607 ha of forest cover fully composed of Aleppo pine, with exceptional damage rates in municipalities of Tamza and Chelia, and this is due to their geo-situation in the south-facing and north-facing versants of the Dj. Aouress mounts, where the topography was an important factor in accelerating the fire spreading over the mounts system.

This study shows that Sentinel 2, dNBR and especially RdNBR are effective data and indices for assessing, classifying and mapping burn severity extent due to wildfire events. Nevertheless, it is important that future researches should be complemented with field assessment, soil analysis and floristic surveys for a better evaluation and more reliable interpretation, related to other ecological factors such as forest stratum (using Composite Burn Index CBI), density, trees species, biomass consumption etc.

Visualizing satellite images shows that the Aures Mounts forests are well equipped with firebreaks system; this could be an effective measure in attenuating the wildfire severity and propagation in such highly-vulnerable areas. Nevertheless, it is also important to adopt appropriate strategies and integrated risk mitigation plans, before, during and after the fire events occurrence.

\section{REFERENCES}

Arellano, S., Vega, J.A., Rodríguez Y Silva, F., Fernández, C., Vega-Nieva, D., Álvarez-González, J.G., RuizGonzález, A.D. (2017) Validation of the remote sensing indices dNBR and RdNBR to assess fire severity in the Oia-O Rosal (Pontevedra) wildfire in 2013. Revista de Teledetección, 49, 49-61.

Benkheira, A. 2018. Forest fires in Algeria: analysis and perspectives. General Directorate of Forests. Ministry of the Interior and Local Authorities (DZ). Last access on July 2021, https://www.interieur.gov.dz/images/LES-FEUX-DE-FORTS-EN-ALGRIE--ANALYSE-ETPERSPECTIVES--Pr-Benkheira.pdf, (Original title in French).

Cai, L. \& Wang, M. (2020): Is the RdNBR a better estimator of wildfire burn severity than the dNBR? A discussion and case study in southeast China. Geocarto International, DOI: 10.1080/10106049.2020.1737973

Cocke, A.E., Fulé, P.Z., Crouse, J.E. (2005) Comparison of burn severity assessments using Differenced Normalized Burn Ratio and ground data. International Journal of Wildland Fire, 14, 189-198

Furtună, P. \& Holobâcă, I.H. (2013) Forest fires study using remote sensing and meteorological indicators. Study Case. Geographia Technica, 8(2), 23-37.

Kazi Tani, M.N. \& Oussedik, M.M. (1977) Geological Map of Algeria, Sheet of Khenchela, Ministry of Industry and Energy, Algeria, (Original Title in French).

Konkathi, P. \& Shetty, A. (2021) Inter comparison of post-fire burn severity indices of Landsat-8 and Sentinel2 imagery using Google Earth Engine. Earth Sci Inform, 14, 645-653.

Madoui, A. (2002) Forest fires in Algeria: history, report and analysis. Foret Méditerranéenne, tome XXIII (1), 23-30, (Original title in French). 
Mallinis, G., Mitsopoulos, I., Chrysafi, I. (2018) Evaluating and comparing Sentinel 2A and Landsat-8 Operational Land Imager (OLI) spectral indices for estimating fire severity in a Mediterranean pine ecosystem of Greece. GIScience \& Remote Sensing, 55(1), 1-18.

Meharzi, M.K. (1994) The role of orography in the spatial distribution of precipitation in the Aures Massif. Méditerranée, tome 80, 73-78, (Original title in French).

Merdas, S. (2007) Report of forest fires in some Algerian governorates, cases of east Algeria: Bejaia, Jijel, Setif and Bordj Bou-Arreridj, University Mentouri of Constantine, Algeria, (Original title in French).

Mitsopoulos, I.D. \& Dimitrakopoulos, A.P. (2007) Canopy fuel characteristics and potential crown fire behavior in Aleppo pine (Pinus halepensis Mill.) forests. Ann. For. Sci., 64, 287-299.

Parajuli, A., Gautam, A.P., Sharma, S.P., Krishna, K.B., Sharma, G., Thapa, P.B., Bist, B.S., \& Poudel, S. (2020) Forest fire risk mapping using GIS and remote sensing in two major landscapes of Nepal. Geomatics, Natural Hazards and Risk, 11(1), 2569-2586.

Parks, S.A., Dillon, G.K., Miller, C. (2014) A New Metric for Quantifying Burn Severity: The Relativized Burn Ratio. Remote Sens., 6, 1827-1844.

Quintano, C., Fernández-Manso, A., Fernández-Manso, O. (2018) Combination of Landsat and Sentinel-2 MSI data for initial assessing of burn severity. Int J Appl Earth Obs Geoinf, 64, 221-225.

Rahmani, S. \& Benmassoud, H. (2019) Modeling of forest fire risk spatial distribution in the region of Aures, Algeria. Geoadria, 24(2), 79-91.

Rogan, J. \& Franklin, J. (2001) Mapping wildfire burn severity in southern California forests and shrublands using enhanced thematic mapper imagery. Geocarto Int., 16(4), 91-106.

Rouse, J.W., Haas, R.W., Schell, J.A., Deering, D.W., Harlan, J.C. (1974) Monitoring the vernal advancement and retrogradation (Greenwave effect) of natural vegetation. NASA/GSFCT Type III Final report, Greenbelt, MD, USA.

Roy, D.P., Boschetti, L., Trigg, S.N. (2006) Remote Sensing of Fire Severity: Assessing the Performance of the Normalized Burn Ratio. IEEE Geoscience and remote sensing letters, 3(1), 112-116.

San-Miguel-Ayanz, J., Oom, D., Artes, T., Viegas, D.X., Fernandes, P., Faivre, N., Freire, S., Moore, P., Rego, F., \& Castellnou, M. (2020) Forest fires in Portugal in 2017. In: Casajus Valles, A., Ferrer, M., Poljanšek, K. \& Clark, I. (eds.) Science for Disaster Risk Management 2020: acting today, protecting tomorrow, EUR 30183 EN, Publications Office of the European Union, Luxembourg.

UNOSAT/UNITAR, 2012. Wildfires in northern Algeria 18 august 2012. Palais des Nations, Geneva, Switzerland. Last access on July 2021, https://reliefweb.int/map/algeria/wildfires-northen-algeria-18august-2012. 